\title{
HORATIO ALGER WITH A JUMP SHOT: MICHAEL JORDAN AND THE AMERICAN DREAM
}

\section{Mary McDonald}

I used to say this man was the Babe Ruth of basketball. I've now come to believe that Babe Ruth was the Michael Jordan of baseball... He's living the American dream. The American dream is reaching a point where you do everything you want to do and do not do anything you don't want to do.

Chicago Bulls owner Jerry Reinsdorf on Jordan's retirement

After Michael Jordan led the Chicago Bulls to the first of what would be three consecutive National Basketball Association (NBA) championships, Sports Illustrated (SI) honored the occasion by naming Jordan the magazine's "1991 Sportsman of the Year." The cover of that December 23 issue featured a hologram of Jordan smiling in three dimensions set across the red and black signature colors of both his team, the Chicago Bulls, and the Air Jordan line of Nike athletic sneakers. This multi-dimensional image was not only a first for $S I$, but according to publisher Mark Mulvoy represented one of the most ambitious holograms ever mass-produced. Apparently conventional forms of representation could not capture Jordan's iconic status.

Consider the procedure Jordan endured while filming the pictures which would compose the hologram cover. According to hologram "artist" Sharon McCormack, Jordan had to sit patiently while being filmed and rotated 120 degrees at approximately one and one third revolutions per minute. Sitting quietly, Jordan had to slowly start smiling, increasing the width to its maximum. "Michael had a very hard job," says McCormack. "He had to smile and exude charisma in slow motion while keeping his body perfectly still. He couldn't even blink. He was very graceful and smooth" (Quoted in Mulvoy 4).

Richard Dyer offers a salient take on this quality of charisma which Jordan exudes, apparently even when motionless. Charisma, the possession of some exceptional, seemingly superhuman quality or qualities, must always be situated culturally and historically among the various ideologies, ambiguities and contra- 
dictions of a particular era. Charisma is best understood as the star's ability to negotiate historically specific instabilities and contradictions.

In this paper I sketch out some of the significant issues, debates and ambiguities which help to generate Jordan's popularity and status as cultural icon. Jordan's appeal can be interpreted as a testament both to his own agency in crafting a tremendous athletic talent and salable public persona as well as to the convergence of a variety of cultural needs, practices and discourses within a particular historical moment. I focus my analysis on Jordan's initial career in professional basketball which spans the years of 1984-1993, as this is the period when Jordan rose to widespread visibility. This time frame parallels the ascent of the Reagan-Bush era, a unique historical epoch characterized by a shift away from the visible political activism of the 1960s and 1970s and toward socially conservative world views.

First emerging under the leadership of President Ronald Reagan and continuing through today, this period, also known as post-Reagan America, nurtured an increasingly vocal rhetoric which championed a return to "traditional family values." These values were hardly traditional, but rather allowed for the sanctioning of backlash politics generated most prominently by the New Right. These backlash campaigns had significant consequences: during the Reagan-Bush era, civil rights legislation was rolled back and anti-pornography campaigns were waged against artists, while corporate freedom and capital expanded. This period saw a stifling of civil rights for both people of color and white women, a growing national deficit and a shrinking middle class (Giroux).

According to some conservatives, economic problems could be traced to the "permissive" and "hedonistic" policies of big government. Bleeding heart liberalism, characterized by the expansion of the state's social entitlement programs including Roosevelt's New Deal and Lyndon Johnson initiated Great Society and War on Poverty programs, merely offered a perversion of traditional American values. Illegitimate birth rates, joblessness and welfare dependency were all created and/or reinforced by "economic incentives to bear out-of wedlock children and the disincentives to work created by the Great Society" (Edsall and Edsall 15).

Placing the future of America in the hands of God, family and traditional values, Ronald Reagan and the New Right skillfully mobilized the racist and sexist sentiments of everyday working middle class Americans to demonize collectivism while advocating policies which favored individualistic and pro-business agendas (White). Economically this meant the implementation of supply-side economic policies, tax breaks for the wealthy, deregulation of big business and heavy investment in military spending.

The supply-side policies of Reaganomics proved to be profitable for the rich as the economic gap widened between rich and poor, a divide greater than at any time in US history (Howe). No less a cultural authority than People magazine offers a chilling perspective of the Reagan-Bush era during the 1980s, noting that large scale economic changes made for "bad manners, mudslinging and machismo" (Lacayo 6). For example, the 1980s were: 
10 perilous years when the whole of public life took on the atmosphere of a slam dance being cheered by a hockey crowd... Why did it happen in the ' 80 's?... it could have been the voodoo in the economy, where over the decade the stock market boomed, but purchasing power declined and took two paychecks to provision one household. The struggle to make ends meet can give a certain Darwinian sharpness to daily life. (Lacayo 102)

The purpose of this project is to locate Jordan within the historical context of the Reagan-Bush era and to make connections across that context. As an athlete, Jordan is immediately linked to some of the prominent themes imbedded in American history as sport connotes the "traditional" values of hard work, teamwork, character-building, competition and discipline. These ideologies took on added significance during the Reagan-Bush era, often serving to justify economic and social policies which largely favored the wealthy. Thus part of Jordan's iconic status can be attributed to the ways his All-American image intertwine with and articulate the socially divisive tenor of the times.

My thinking has been greatly influenced by cultural studies approaches which suggest that "culture is ordinary." Thus my analytical focus is on everyday popular culture, "on the structures and practices within and through which modern societies construct and circulate meanings and values" (Brantlinger 37). Cultural analysis is a theoretical and political endeavor which explicates the meanings of cultural forms while offering criticism and commentary on asymmetrical social relations, particularly those related to race, class and gender.

In this paper I explore representations of Jordan in several textual artifacts: advertisements, books, televised games, highlight videos, magazines and newspaper sport sections. Indeed this is an easy task as Jordan is highly visible in both sporting and advertising discourses. At the time of Jordan's initial retirement from basketball in 1993, Forbes magazine estimated Jordan's 1993 “Madison Avenue" income topped all other athletes at \$32 million (Lane and Midgitt).

I am not interested in revealing the "real" person behind the public image of Michael Jordan. Rather I examine the converging mediated discourses surrounding Jordan in order to analyze the crafted image of Jordan much as someone would read a text to offer commentary. Such "textualization" is actually a methodological strategy to explore the social relations and ideologies which make up the larger world(s) we inhabit (Turner).

Stuart Hall recognizes the discursive and semiotic character of cultural ideologies, suggesting that ideologies serve as systems of representations or "systems of meaning through which we represent the world to ourselves and one another" (101). Social relations and world views are represented in speech, language and signifying practices to acquire meaning and that "is why we have to deconstruct language and behavior in order to decipher the patterns of ideological thinking which are inscribed in them" (97).

\section{Here Comes Mr. Jordan}

The genesis of Michael Jordan's carefully crafted, highly marketable image begins with an often told tale. Cut from Laney High School's varsity basketball 
team as a sophomore in Wilmington, North Carolina, Jordan turned initial defeat to his advantage, honing his skills all summer to emerge as a great player the following season. Jordan's logic: "When a lot of people figured I couldn't do something, that gave me the challenge to do it" (Quoted in Smith 9).

This parable reflects a classic American world view which suggests that freedom, opportunity and material success are available to all through hard work and persistent effort. The American Dream is an ideology designed to reify the contention that America's democratic vision and capitalist economic system are fundamentally fair despite enormous disparities in wealth and social status (Jhally and Lewis).

Jordan's quote also reflects the world view of Jordan's corporate sponsor, Nike, which implores consumers to "Just Do It," suggesting a do-it-yourself mentality is the way to improved fitness, health and consumption. The sentiment expressed by Jordan and Nike resonates with some of the prominent slogans of the Reagan-Bush era, one of the most popular being "Just Say No," the cliché from the national anti-drug campaign whose leading proponent was First Lady Nancy Reagan. This slogan was a rallying point and was offered as a viable solution for the apparent moral decay and crisis of drug abuse in this country (Reeves and Campbell).

Jordan's and Nike's will to "Just do it," like Nancy Reagan's "Just Say No" campaign, articulated the discourse of self-improvement and affirmation of Reaganism, a simplistic sentimentality of renewal, revival and individualistic action (Reeves and Campbell). The master narrator of this vision was Reagan himself who offered compelling images, words and myths to resolve personal and public crises. These rhetorical appeals, far from being the province of Ronald Reagan, are endemic to America. Their reverberation throughout the culture during the Reagan-Bush era was an attempt to renew faith in consumer capitalism by affirming mythic tales of individualism, community and the American Dream (Morreale; Reeves and Campbell).

The power of the American Dream is that it is widely available in all forms of popular culture. Besides sporting narratives, both the television and film industries contribute with mythic depictions of rags-to-riches stories. "This whole materialistic charade is fueled by the most influential cultural industry in the United States: advertising" (Jhally and Lewis 140). The overwhelming message of ads, according to Jhally and Lewis, is to consume, to exist in a state of want and constant material desire.

"From the very beginning of his professional career, Jordan was consciously marketed by his agency ProServ as a peripatetic vehicle of American fantasies of capital accumulation and material consumption tied to Jordan's personal modesty and moral probity" (Dyson, 1993b, 68). While stories like Jordan's achievement of the American Dream of material success are endemic to sport and American culture, in post-Reagan America this type of narrative served another function. They provided the organizing theme to promote the resurrection and elevation of celebratory tales of success which lent credibility to individualist and elitist policies upon which social and economic policies were based. They helped to 
legitimate the contention of Reaganomics that economic growth depends upon what Reeves and Campbell characterize as a type of "reverse Robin Hoodism," the slashing of taxes for the wealthy while cutting the social programs which aid the poor.

During the Reagan-Bush era economic and social policies widened the economic gap between wealthy and poor Americans (Clarke). Icons of success such as Michael Jordan filled an ideological void suggesting that achieving the American Dream is a matter of personal perseverance rather than the province of those born into privilege (Reeves and Campbell). Thus the American Dream, achieving the seemingly justified material fruits of hard work and labor, reinforces the desirability of individual autonomy upon which the ideology of rugged individualism is based.

Jordan's success in sport and advertising is powerful, resonating especially with similar depictions of people of color achieving individual distinction. These images proved to be significant, masking the perils of "reverse Robin Hoodism" which disproportionately affected people of color, offering an illusion of equality for all (Reeves and Campbell). Both Ronald Reagan and George Bush presided over budget cuts, program changes and reorganizations in social programs while opposing school busing, affirmative action and an aggressive enforcement of civil rights laws (Shull).

As David Andrews has argued, perhaps the best example of an individual who embodies the tremendous material success and public acclaim celebrated in post-Reagan America is that of Bill Cosby. Cosby wrote a best-selling book in 1986 entitled Fatherhood and his television creation, The Bill Cosby Show, enjoyed top rated status "year after year in the second half of the 1980's" (Jhally and Lewis 1). The parallels between Bill Cosby's character Cliff Huxtable and Michael Jordan are significant. Both began a run of national success in 1984, the year of Reagan's re-election, although Bill Cosby had prior ventures as a stand up comedian and actor, most notably as the costar of the 1960 s television show, $I$ Spy (Lewis and Jhally). Cosby is also identified with commercial sponsors, most prominently Jell-O, just as Jordan is for Nike. Finally, both figures are linked to kindred narratives, including that of the American Dream and an appreciation of family life and children.

Just as Jordan successfully created a marketable image of black masculinity by proving the will to "Just Do It," so too did Bill Cosby consciously set out to construct a positive vision of black family life. The Bill Cosby Show features a nuclear family with father, Cliff Huxtable, as a successful obstetrician and mother, Claire, as a prominent lawyer. The two have five loving, obedient children and as the seasons pass, the Huxtable family is extended with in-laws and grandchildren. Living in a comfortably decorated house, the Huxtables have accumulated the ultimate markers of success, living in the lap of consumer comfort and familial bliss (Lewis and Jhally).

Cosby purposely created the show's characters to counteract negative stereotypical mediated images which feature narrow, distorted and negative depictions of blackness. There is a long history of this distortion and misrepresentation. 
Early film images offered socially constructed caricatures of African Amer1cans, visually depicted as the coon, the buck, the clown, the mammy, the darky, the spook, the shiftless shine and the shuffling Negro (Dyson, 1993b). Radio and then television merely updated these conventional practices.

Even when there has been growth in representing black characters, television has often presented problematic versions of racial progress. With the likes of George Jefferson, J. J. "Kid Dyn-o-mite" and Arnold or Webster, blacks were either highclass variations on the theme of the clown, or filling another social slot as a stereotypical slum dweller, or beneficiaries of white patrons-cum-adoptive parents, whose largesse brought domestic stability and upward mobility to chosen black children. (Dyson, 1993b, 79)

Battling history and an unsympathetic entertainment industry, Cosby offered the Huxtables as an alternative to these stereotypes. Ironically, the depiction of the Huxtables as an upper-middle class family suggests that the show is representative of only a minority of Americans, a privileged few (Lewis and Jhally). Critics such as Marc Crispin Miller note the show's tendency to downplay the significance of race while elevating the desirability of the American Dream, a plot which Jordan has also embraced. Cosby steadfastly defends this strategy: "My point is that this is an American family - an American family - and if you want to live like they do, and you're willing to work, the opportunity is there for you" (Quoted in Zoglin 60).

Jordan's reading of the larger meaning of his own athletic and advertising success follows this sentiment as well.

I think sometimes I'm looked upon as not just a black person but as a person. And I think that's totally new ground for us-and for society. I'm happy to be a pioneer. When I say, "Don't think of me as white or black," all I'm saying is: "View me as a person." I know my race and I know you know what my race is—but don't magnify it to let me know what my race is when I already know that. You've got all these white kids who look up to me. They aren't old enough to see color yet. If they see me not as a black man but as a person they wish they could be like, they enjoy watching, enjoy meeting and being around, that's fine, I'm accomplishing a goal. (Quoted in Breskin 396)

Thus Cosby and Jordan echo a significant theme of Reaganism: an appeal to a universal colorless culture which ignores the structural and ideological components of racism. In discussing the Huxtable family, Lewis and Jhally offer an analysis of the ideological significance of black success during the era of Reagan-Bush. This critique is also instructive for understanding Michael Jordan.

The Cosby Show, by incorporating a black family into the American dream, plays an important part in this ideological process. It symbolizes the fairness of the American system. The fact that the Huxtables are an African American family is central to this process: their success assures us that in the United States everyone, regardless of race or creed, can enjoy material success. (73)

With this type of commonsense understanding, The Cosby Show and Jordan are hailed by many white Americans in general, and by key members of the New Right in particular, as proof that racism in American has been eradicated and that the American Dream is available to those blacks who could pull themselves up by 
their bootstraps (Lewis and Jhally; Andrews; McDonald). This type of sentiment suggests that those African Americans who find themselves in poverty only have themselves to blame.

Nationally syndicated columnist and New Right apologist, William F. Buckley, Jr., proved to be the exemplar of the notion that inequality has been eradicated by stating:

It is simply not correct, the evidence of one's senses confirms, that race prejudice is increasing in America. How does one know this? Simple, by the ratings of Bill Cosby's television show and the sales of his books. A nation simply does not idolize members of a race that nation despises. (Quoted in Demeter 67)

The elevation of a television character to offer ideological "proof" of a more enlightened society, reinforces the "bootstraps" mentality of the Reagan-Bush era. Yet, it is the larger cultural awareness of Bill Cosby which is key in this process, for Lewis and Jhally argue that behind "the fictional doctor lies a man whose real life is also a success story: fact and fiction coalesce to confirm the 'truth' they represent" (8). This blurring of the apparent distinctive elements of fact and fiction comes full circle in the ideological message the show represented. If the American Dream proved to be unattainable, the fault was not with governmental and societal indifference, but rather in the presumed pathological status of black America. In short, people of color proved to be their own worst enemy (Demeter).

\section{Reading Sport: The Game Behind the Game}

Just as with Cosby, the blurring of fact and fiction has coalesced as Jordan has constructed a marketable public persona. Jordan the advertising creation is often difficult to distinguish from Jordan the athlete (Andrews). Indeed the two are intrinsically linked every time Jordan laces up a pair of Air Jordans to play a professional basketball game. Furthermore, the illusion of apparent neutrality and naturalness is prominent in sport where, unlike the plots of The Cosby Show, the outcome of contests are never certain. Jordan's body then becomes a powerful site for the articulation and contestation for some of the individualistic affirmations of Reaganism.

The association with commercialized sport provides a powerful entry into the ideology of individualism or the bootstraps mentality which was widely promoted during this period. The structure of commercial sport and mediated sporting narratives have long assisted in the creation and celebration of parables of individual success and freedom. Susan Birrell makes exactly this point noting that sport

as a meritocracy based on skill quietly reaffirms our national commonsense: individuals who work hard and possess the right stuff will always prevail. Turned on its head, this lesson becomes even more insidious: those who are at the top must have risen to the top through fair means and thus deserve their position. In contrast those not at the top do not possess the requisite talent for such privilege. Even the runner-up is a loser. (213) 
The perceived status of sport as freely chosen leisure separate from political influence make it an especially powerful site for the articulation of particular world views (Sage). Despite evidence to the contrary, professional sport, in conjunction with a largely uncritical sports media, has long promoted itself as a benevolent industry which fosters many dramatic tales of individual achievement.

The entanglement of sports journalism in alliances of power and particular ideologies which promote the American Dream is important to note. Journalists play a central role in the construction and reconstruction of reason and nonreason by presenting particular world views as if they were commonsense (Jhally; Reeves and Campbell).

The themes promoted by sportswriters echo throughout the advertising and corporate worlds as well. Sut Jhally suggests that the relationship between professional sport industries, sports journalists, advertisers and individual athletes is a mutually beneficial one characterized as the sport/media complex. This is an especially emotionally powerful arrangement as most people experience sport as spectators: the cultural experience of sport is largely a mediated one (Jhally).

Under the direction of ProServ, his marketing agency, Jordan is part of this mutually beneficial economic union in which each component sells the other. Sport has long served as fodder for media forms including radio, television and newspapers which need to fill air and print space with interesting copy while delivering presumably male consumers for advertisers. Likewise sport entrepreneurs and athletes have reaped economic rewards thanks to the visibility offered them via media and advertising discourses. Thus media legitimation of Michael Jordan is nothing new; rather it is the most recent example of a mutually-beneficial union.

While professional sport has increasingly relied upon media and advertising revenue for survival, the role of sports journalists in promoting sport and individual athletic feats of (usually) masculine prowess has a long history. Think only of the grand icon of sporting achievement, Babe Ruth, who benefited from the sportswriting prose of a group of reporters that emerged to promote the 1920s as the Golden Age of Sport: Ring Lardner, Grantland Rice, Heywood Broun, and John Kiernan among others (Susman). The grand narrative these writers crafted to promote the star player of the New York Yankee baseball dynasty of the 1920s and 1930s suggests that Ruth triumphed in the athletic arena, escaping a childhood of deprivation and poverty (Sobol).

While decades and distinctive historical contextualization separate the two, Warren Susman's astute analysis of Ruth as an "ideal hero for the world of consumption" also seems particularly apt for understanding the creation of Jordan's image. Over a half century before Jordan, Ruth proved to be a particularly attractive commodity benefiting from sportswriting prose which exploited his extraordinary athletic talent, masculine presence and embraceable personality complete with a rags-to-riches story line (Susman).

Just as Jordan sought the services of agent David Falk, so too was Ruth active in making himself into a marketable performer by hiring agent Christy Walsh who arranged barnstorming tours and scheduled acting jobs in the movies and 
vaudeville for Ruth. Walsh created a favorable impression of Ruth by hiring prominent sportswriters to pen ghostwritten stories with Ruth's byline. Before the age of Ruth, baseball players received minor endorsement deals, if any. Under the guidance of his agent and in a climate conducive to consumption, Ruth hawked menswear, alligator shoes, hunting and fishing equipment, baseball gear, smoking paraphenalia and automobiles in New York newspaper advertisements (Sobol). Much like the Air Jordan line of athletic apparel and shoes, Babe Ruth sweaters, caps, scoring aids, dolls, socks, gloves and uniforms also flooded the market. Ruth's non-baseball earnings during his fourteen-year career were well over two million dollars in total, a figure which would be much more substantial if converted to today's inflationary economy (Sobol).

While the basic formulaic narrative of individualism and the desirability of consumption have remained intact since the time of Ruth, the meanings of this narrative have shifted over the course of time. William Buckley should take note: in the post-civil rights era this myth of meritocracy in sport has taken on a distinctive tenor as it relates to African Americans. Sport, the commonsense story goes, provides a level playing field for all. The best and most talented, regardless of race, can rise through the sporting system and receive their just economic rewards. Yet, the numbers hardly substantiate this claim. Sport has proved to be an avenue for reaching the American Dream of material success for only a small percentage of people of color: "Fewer than 3,600 jobs exist in professional sports, so the potential for sport to directly provide social mobility for significant numbers of people is largely imaginary" (Sage 41). Additionally, sociological studies reveal that the vast majority of Americans remain in the socio-economic categories in which they were born (Sage).

Jordan is one of many prominent African-American athletes who seemingly embody and thus legitimate the ideologies of individualism and the desirability of the American Dream. Not surprisingly in an era distinctive for the symbolism placed on the black body, the Reagan era saw the assent of what Cindy Patton characterizes as the "Africanized Horatio Alger trope of athletes" who possess the (New) Right stuff with modest beginnings, skill, desire, determination and marketing savvy (Quoted in Cole and Denny 129).

Even before Jordan played a game in the NBA, in the early 1980's, Earvin "Magic" Johnson had parlayed an Algeresque image (while leading the Los Angles Lakers to several championships) into what the December 3, 1990 cover of SI championed as "Magic Inc." The accompanying photo is particularly telling featuring Johnson nattily attired in a blue pinstriped business suit reclining in a leather executive chair hovering over the cut line "Earvin Johnson is lighting up the Business World." With the trademark "Magic" smile plastered across his face, his right arm set heavenward as if to suggest "what can I say," his left hand fingers the classic masculine symbol of success, a large stogie cigar.

The text is equally laudatory, noting Johnson's commitment to rise above his working-class roots in Lansing, Michigan. As a teen taking a cleaning job in an office building, Johnson would often envision his future. 
"I'd sit back in one of those big chairs and put my feet on the desk," Magic says, "and start giving orders to my staff. 'Do this, do that." It was fantasy stuff just like the basketball games he would play in his head. He had no idea what he was telling his staff to do except that it involved the achievement of truly big business. "I'm a big dreamer," Magic says. Then: "For some reason, I'd still like to own an office building." (Hoffer 110)

\section{Making Michael: A Dream}

By the time he took a brief retirement from professional basketball in October 1993, Jordan had acquired tremendous material wealth and public acclaim. Over the course of his basketball career Jordan led the once hapless Bulls to three consecutive NBA titles while winning individual accolades such as the Most Valuable Player Trophy three times. Like their praise for Magic Johnson, sports reporters lauded the ways Jordan achieved these goals noting his ability to blend exceptional individual skills into the workings of the team (Naughton).

These achievements proved to be the completion of a carefully orchestrated and by then well-established image. Early in Jordan's professional basketball career, agent David Falk, Nike account creator and Wiedon and Kennedy employee Jim Riswold and NBA promoters all assisted in crafting yet another marketable story line. In an era known for promoting mythical tales to serve particular purposes a bit of embellishment was necessary, for Jordan deviates somewhat from the working-class roots of Johnson and the poverty of Ruth. With a modest middle-class background, the classic tale of overcoming early economic hardship, the proverbial rags-to-riches tale, could not be invoked here. The story which defines Jordan's image then is the disappointment of being cut from the high school team: Jordan's humble beginnings begin with an impoverished basketball talent.

Jordan is active in recreating this image for himself. In the first of three home videos about Michael Jordan produced in 1989 by CBS Fox in cooperation with NBA Entertainment, entitled Michael Jordan: Come Fly With Me, a shot of the Laney High School sign appears with the following voice-over: "But greatness sometimes springs from humble beginnings. As a five-foot-eleven sophomore, young Michael was noticeably absent from the varsity team" (Sperling).

The scene shifts to Laney High School coach Fred Lynch who expresses a particularly salient confession.

Yes, I' $m$ the coach who cut Michael as a sophomore. We thought at the time it was the best thing for him and our basketball program. He was still growing, he was a good ball player, but we did not think he was good enough yet to make the contribution on the varsity that we needed. (Sperling)

Against images of Jordan running and scoring on the basketball court the announcer booms:

Determined to prove his coach wrong, Michael Jordan worked harder than ever, growing four inches and improving dramatically over the next two years. He would shatter all of Laney's scoring records while leading the Buccaneers to their first ever conference championship. (Sperling) 
This triumph-over-tragedy narrative proves to be the entire plot for the next video entitled Michael Jordan's Playground which was produced in 1991. Here Jordan's experience of being cut from the team provides the basis for a fictional story line featuring young Walt Preston who did not make his Eastside High School basketball team. The words of Preston's would-be coach ring out over and over as Preston practices diligently on the playground: "For those of you guys who did not make it, Michael Jordan got cut from his high school basketball team and he came back a better player." Then amidst Svengali music which suggests spirituality, Jordan makes a God-like visitation offering athletic dispensation to a stunned Preston.

Complete with action highlights of Jordan's most spectacular moves set to music and vignettes featuring fellow NBA players and coaches lauding Jordan's extraordinary talents the story within the story progresses.

Jordan: In the NBA, there's a lot of great athletes, but it's your determination which sets you apart.

Preston: I hustled and I hustled and I played as hard as I could but it did not matter.

Jordan: O.K. Why did you get cut?

Preston: Because I got abused. I mean coach had his mind made up. There was nothing I could do.

Jordan: Well you go back and change his mind. Look, when I first came into the league all people thought of Michael Jordan was look at him dunk or how many points did he score. No one really knew that I could play defense. That's what you need to do. You got to show them that you're tough-you can do what you need to do to win. (Sperling)

Predictably, due to Jordan's wise counsel and encouragement, Preston makes the team and is even singled out by the coach for spectacular play. The story concludes with a music video featuring Jordan and the group, the "Full Force All Stars" singing and dancing to the tune "Anything's Possible," interspersed with game highlights of Jordan. The message for the audience is unmistakable: success or failure reside in the hands of individuals and failure can not be blamed on any institutional or ideological barriers. Individual effort is all that matters: just do it.

\section{Love of the Game}

Overcoming adversity is a recurring theme in the discourses surrounding Jordan. While the story about his high school defeat and triumph was consciously embellished and retold to establish Jordan's character, a couple of publicized incidents early in his career provided Jordan with additional sympathy. As a second-year pro, Jordan broke his left foot and was forced to sit out the majority of the basketball season.

While sportswriters lamented Jordan's time away from the game his status was discussed much differently in the pages of Advertising Age. "Any time an athlete is hurt, there is a natural dampening of enthusiasm in some marketing programs, but that is purely a psychological point of view," said Donald Dell, chair of ProServ, Jordan's representative agency. "It is rather ironic in that he had more 
time for personal appearances and photo opportunities," continues Dell (Quoted in Fitch 16). Indeed, during his recuperation Jordan was able to solidify his position in the advertising world spending time with individuals from Nike, Coca Cola and McDonald's. After his injury Jordan came back to set an NBA scoring record. "You can't buy that kind of PR value," said Dell. "His injury had a happy ending" (Quoted in Fitch).

The incident's resolution provided apparent proof that Jordan was worthy of public admiration, for unlike other highly paid athletes, Jordan possessed a true love of the game. Ignoring the wishes of both the Bulls management and his agent, David Falk, Jordan rejoined the team just in time to lead them into the playoffs.

Bob Sakamoto (1986a) of the Chicago Tribune placed this spin on the incident:

Usually, Michael Jordan isn't a disobedient kind of a guy. But this is one time the Bulls are glad he is going to do things his own way. The injured superstar was advised by his agent David Falk to sit out the remainder of the season while recuperating from a broken bone in his left foot. Jordan politely said no. (1)

For Jordan to "just say no" proved his self-reliance by standing up to those who would deny his love of the game. Opting for damage control, Bulls owner Jerry Reinsdorf and general manager Jerry Krause finally acquiesced to Jordan's demands with one stipulation: limited playing time (Sakamoto, 1986b). Still Jordan was defiant, accusing management of not being committed to winning, and the evolving soap opera played out in the pages of the Chicago Tribune.

Chicago Bulls beat writer Bob Sakamoto (1986c) published Jordan's suspicions that the Bulls were limiting the playing time of the team's best player to qualify for the college draft lottery, which is awarded to the teams with the league's worst records.

\footnotetext{
"Losing games on purpose reflects what type of person you really are," Jordan said. "No one should always try to lose to get something better. You should always try to make the best with what you have. If they really wanted to make the playoffs, I'd be in there whenever we had a chance to win a game." (6)
}

There is a message in Jordan's defiance which can be ascertained only by examining who and what Jordan challenged, for Jordan was standing up to the absurdity of needless regulation and authority which stifled both his personal creativity and the team's production. Jordan would get into another well-publicized tiff with management the following season for similar reasons: Jordan accused then head coach Doug Collins of fudging the score, placing Jordan's team on the losing end during a practice scrimmage. Jordan stormed out of the gym fearing he would say something he'd regret later and, according to Collins, "it seemed like he didn't want to listen to me" (Quoted in Sakamoto, 1987, 1).

"I would have been steaming," [Jordan] said. "It would've just been like the time I broke my foot. I couldn't just sit there and watch my team lose. So I came home and cooled off. It's my competitive attitude. I want to win, and I don't want people stacking the odds against me to make me lose." (Quoted in Sakamoto, 1987, 4) 
These scenarios sound surprisingly like the plots of some of the most popular films of the Reagan era. So too did masculine heroes of 1980s popular films act heroically, not in defiance of a corrupt society, but in defiance of large and ineffective institutional bureaucracies. As Susan Jeffords argues, hard-bodied action heroes like John Rambo are pitted against bureaucrats who have lost touch with what's really important and have thus failed to meet the needs of individuals. This of course is the primary theme of Reaganism, decreasing the size of government itself and cutting unwieldy bureaucracies to serve the real desires of average Americans (Jeffords).

When injured, Jordan thinks only of his desire to play basketball.

It's a risk for me, but it's not a financial decision. Basketball is my dream, my love. I' $m$ not worried about the financial part...I' $m$ not a piece of property. I don't care what they pay me. I'm still a human being. (Quoted in Sakamoto, 1986d, 4)

A happy ending is found in both scenarios with management's realization that Jordan was right all along. The needs of the individual player are ensured during Jordan's next contract negotiation in 1988 in which Jordan signs for \$28 million over eight years, making him the highest paid player in team sport history (Sakamoto, 1988). As equally publicized as those figures was a unique provision known as the "love of the game" clause. This provision reaffirms Jordan's right to play basketball anytime he wishes, protecting him from liability from any basketball related injury. Owner Jerry Reinsdorf has come full circle: "Maybe this isn't the best decision, but how can I say no to Michael Jordan" (Quoted in Sakamoto, 1988, 5).

The "love of the game" clause distanced Jordan from public perception of individual greed. In an age where athletes' salaries are rapidly escalating, Jordan is the embodiment of a nostalgic and seemingly purer vision of what sport was meant to be all about: something to be pursued for enjoyment and fun. The "love of the game" clause suggests that Jordan is not an aloof hero; rather, Jordan represents an every-day American possessing a healthy dose of passion, talent and self-reliance. With hard work and persistence, the athlete who was once cut from the high school team has earned $\$ 28$ million receiving the just rewards of a "fair" system. Michael Jordan is the embodiment of the American Dream, lending further credibility to what Reeves and Campbell identify as a central tenant of Reaganism: history is made through the inspirational acts of outstanding individuals.

\section{Works Cited}

Andrews, David. "Deconstructing Michael Jordan: Popular Culture, Politics, and Postmodern America." Diss. U of Illinois, 1993.

Birrell, Susan. "Racial Relations Theories and Sport: Suggestions for a More Critical Analysis" Sociology of Sport Journal 6 (1989): 212-227.

Brantlinger, Patrick. Crusoe's Footprints: Cultural Studies in Britain and America. New York: Routledge, 1990.

Breskin, David. "Michael Jordan, in His Own Orbit." Gentleman's Quarterly March 1989: 318-323, 394-397. 
Clarke, John. New Times and Old Enemies: Essays on Cultural Studies and America. London: HarperCollins Academic, 1991.

Cole, Cheryl and Denny, Harry. "Visualizing Deviance in Post-Reagan America: Magic Johnson, AIDS, and the Promiscuous World of Professional Sport." Critical Sociology 20 (1994): 123-147.

Demeter, John. "Winter in America: Notes on the Media and Race." Radical American 20 (1986): 63-71.

Dyer, Richard. "Charisma." Stardom: The Industry of Desire. Ed. C. Gledhill. London: Routledge, 1991.57-59.

Dyson, Michael Eric. "Be like Mike?: Michael Jordan and the Pedagogy of Desire." Cultural Studies 7 (1993a): 64-72.

Reflecting Black: African-American Cultural Criticism. Minneapolis: U of Minnesota P, 1993b.

Edsall, Thomas and Edsall, Mary. Chain Reaction: The Impact of Race, Rights and Taxes on American Politics. New York: W. W. Norton, 1991.

Fitch, Ed. "Injury Fails to Keep Jordan Off the Air." Advertising Age 1 Sept. 1986: S-16.

Giroux, Henry. "Living Dangerously: Identity Politics and the New Cultural Racism: Towards a Critical Pedagogy of Representation." Cultural Studies 7 (1994): 1-24.

Hall, Stuart. "Signification, Representation, Ideology: Althusser and the Post-Structuralist Debates." Critical Perspectives on Media and Society Eds. R. Avery and D. Eason. New York: Guilford, 1991: 88-113.

Hoffer, Richard. "Magic's Kingdom." Sports Illustrated 3 Dec. 1990: 106-120.

Howe, Irving. "The Spirit of the Times: Greed, Nostalgia, Ideology and War Whoops." Dissent (Fall 1986): 413-425.

Jeffords, Susan. Hard Bodies: Hollywood Masculinity in the Reagan Era. New Brunswick, NJ: Rutgers UP, 1994.

Jhally, Sut. "Cultural Studies and the Sports/media Complex." Sport, Media and Society. Ed. L. Wenner. Newbury Park, CA: Sage, 1989: 70-93.

Jhally, Sut and Lewis, Justin. Enlightened Racism: The Cosby Show, Audiences and the Myth of the American Dream. Boulder: Westview, 1992.

Lacayo, Richard. "America in the '80's Was a Kinder, Gentler Nation." People Fall 1989 (Special Issue): 102-107.

Lane, Randall. and Midget, Warren. "The Super 40." Forbes 20 Dec. 1993: 94-98.

McDonald, Mary. "Clean Air: Representing Michael Jordan in the Reagan-Bush Era." Diss. U of Iowa, 1995.

Miller, Marc Crispin. "Primetime: Deride and Conquer." Watching Television: A Pantheon Guide to Popular Culture. Ed. T. Gitlin. New York: Pantheon, 1986:183-228.

Morreale, Joanne. A New Beginning: A Textual Frame Analysis of the Political Campaign Film. Albany: State Univeristy of NY P, 1991.

Mulvoy, Mark. "From the Publisher." Sports Illustrated 23 Dec. 1991: 4.

Naughton, Jim. Talking to the Air: The Rise of Michael Jordan. New York: Warner, 1992.

Patton, Cindy. "Rock Hard." Keynote paper presented at the annual meeting for the North American Society for the Sociology of Sport Conference. Toledo, OH. November 1992.

Reeves, Jimmie. and Campbell, Richard. Cracked Coverage: Television News, the AntiCocaine Crusade and the Reagan Legacy. Durham, NC: Duke University, 1994.

Sage, George. Power and Ideology in American Sport: A Critical Perspective. Champaign, IL: Human Kinetics, 1990.

Sakamoto, Bob. "Super Sales Pitch By Bulls." Chicago Tribune 24 Oct. 1984, Section 4: 1,5 . Section 4:1.

“Jordan Bucks Agent's Advice to Sit Out." Chicago Tribune 12 Feb. 1986a,

“'Jordan's Comeback Show a Hit: Bulls Revival Draws Flock of NBA Worshipers." Chicago Tribune 19 March 1986b Section 4: 3. 
“"Jordan Rails at Reinsdorf, Krause." Chicago Tribune 3 Apr. 1986c, Section 4:

1.

"Jordan, Reinsdorf Decide to Bury the Hatchet-For Now." Chicago Tribune 6 Apr. 1986d, Section 4: 4.

."Jordan Walks Out After Collins Clash." Chicago Tribune 28 Oct. 1987, Section $4: 1,4$.

“Jordan Gets \$28 Million Deal." Chicago Tribune 8 Apr. 1988, Section 4: 1, 5.

Shull, Steven. A Kinder, Gentler Racism? The Reagan-Bush Civil Rights Legacy. Armonk, NY: M. E. Sharpe, 1993.

Smith, Sam. "Setback as Prep Inspired Jordan." Chicago Tribune 25 Dec. 1984, Section 4: 1,9 .

Sobol, Ken. Babe Ruth and the American Dream. New York: Ballantine, 1984.

Sperling, Don. Michael Jordan: Come Fly With Me. New York: CBS/Fox, 1989.

. Michael Jordan's Playground. New York: CBS/Fox, 1991.

Susman, Warren. Culture as History: The Transformation of American Society in the Twentieth Century. New York: Pantheon Books, 1984.

Turner, Graeme. British Cultural Studies: An Introduction. Boston: Unwin Hyman, 1990.

White, John Kenneth. The New Politics of Old Values. Hanover, NH: University Press of New England, 1988.

Zoglin, Richard. "Cosby, Inc.” Time 28 Sept. 1987: 130, 56-60. 